\title{
Effect of Methanol Root Extract of Senna occidentalis against Carbon Tetrachloride-Induced Hepatic Damage in Rats
}

\author{
Kwalle, Joseph John' ${ }^{1}$, Bello, M.I ${ }^{2}$ \\ ${ }^{1}$ Government Day secondary school Vimtim, Mubi-North local government, Adamawa state, Nigeria \\ ${ }^{2}$ Department of Biochemistry, School of Pure and Applied Sciences, Modibbo Adama University of Technology, P.M.B. 2076 Yola, \\ Adamawa State, Nigeria
}

\begin{abstract}
Protective effect of methanol root extract of Senna occidentalis was investigated against carbon tetrachloride (CCl $)_{4}$ induced hepatic damage in white Wistar strain albino rats. Hepatic damage was induced by injecting a single intraperitoneal dose of $1.0 \mathrm{ml}(50 \%$ volume/volume $\mathrm{CCl}_{4}$ in olive oil. Plant extract $(100,200$ and $300 \mathrm{mg} / \mathrm{kg}$ body weight) was given for seven days. Hepatic damage was induced and the animals were scarified after 48 hours. The hepatoprotective effect of the extract was monitored by estimating the activities of the serum AST (Aspartate Aminotransferase), serum ALT (Alanine Amino Transferase), serum ALP (Alkaline Phosphatase), Total proteins, unconjugated bilirubin and conjugated bilirubin. This observation could be supported by some Phytochemicals detected in the methanol root extract. Results showed that methanol extract of Senna occidentalis possessed hepatoprotective activity by significantly $(p<0.05)$ reversing the damage of the liver indices in the treated experimental animals compared with the $\mathrm{CCL}_{4}$ treated group. Some of the Phytochemicals component detected in the methanol extract of this plant indicated the presence of Flavonoids $(0.8 \pm 0.11)$, Phenols $(12.0 \pm 0.21)$, Tannins $(5.0 \pm 0.26)$, Saponins $(21.5 \pm 0.71)$. Terpenoids $(0.28 \pm 0.04)$ and Alkaloids $(4.8 \pm 0.21)$
\end{abstract}

Keywords: Senna occidentalis, in-vitro antioxidant, hepatoprotective, Phytochemicals screening

\section{Introduction}

High rate of liver disease has been causing death among the adult population globally today (Kuppuswamy et al., 2003) because of the absence of reliable drugs for the treatment and prevention of liver diseases in modern medicine (Etuk et al., 2009). Traditional medicine is considered as the sum total of knowledge, skills and practices based on the theories, beliefs and experiences indigenous to different cultures that are used to maintain health, as well as to prevent, diagnose, improve or treat physical and mental illnesses (WHO report on Traditional medicine in some Asian and African countries 2011). Natural medicinal products are increasingly gaining popularity and used worldwide as complementary alternative therapies (WHO Fifth-Six World Health Assembly report on traditional Medicine; 2003), based on the fact that the raw materials are available naturally and in abundance with an estimated record of 1062-63 potentially beneficial substances. Among such therapeutic preparations are plant-derived phytomedicines, nutraceuticals and cosmeceuticals (Drew, 2000). The critical process underlying $\mathrm{CCl}_{4}$ hepatotoxicity is the combining effect of both lipid peroxidation and the covalent binding of $\mathrm{CCl}_{4}$ reactive metabolites to lipids and proteins (Masuda and Nakamura, 1990). It has been shown that $\mathrm{CC1}_{4}$ induced lipid peroxidation can be obstructed by natural antioxidants (Subramanian et al., 1999). The identification of naturally occurring inhibitors of peroxidation resulting in cell damage could therefore lead to important new strategies for disease prevention (Subramanian et al., 1999). A number of plants have been shown to possess hepatoprotective and hepatocurative effect e.g Carthamus oxyacantha (Bukhsh et al., 2012), but there is still lack of scientific proofs to authenticate the hepatoprotective and hepatocurative properties of some plants which are used traditionally to treat liver disorders. An example of such plant is Senna occidentalis, which has been used for about hundred years by Fali and Gude people from Mubi in Adamawa state of northern Nigeria as a possible remedy to liver problem. Senna occidentalis (cassia occidentalis, L.) is a medium-size flowering shrub belonging to the family caesalpiniaceae, Senna is an ancient Arabic name for these plants and occidentalis is a Latin word means western, and refer to the origin of this plant (Delachiave and De pincho, 2003). Other local names include mama tasba (fulfulde), Negro coffee, stink weed, rere (Yoruba),akedeagbora and ikpammuo (Ibo) (Bhar et al., 1990). It is known as "coffee Senna", since its seed are brewed into a coffee-like beverage for asthma and its flower infusion is used for bronchitis in the Peruvian Amazon and its leaf extract exhibit broad-spectrum antibacterial (Sam and Ignacimuthu, 2000), antifungal activities (Jain et al., 1998). While the leave powder and extracts have proved to be in the control of large variety of insects (Dwivedi and Kumar 1998). It has also been used to reduce the number of mosquitoes indoors (Palsson and Janenson 1999).

\section{Material and Methods}

\section{Collection of plants materials}

Root of Fresh matured Senna occidentalis plant was collected from Girei local government area of Adamawa state in the month of October 2014. The plant material was identified by the Botany Department of Modibbo Adama University of Technology Yola. 


\section{International Journal of Science and Research (IJSR) \\ ISSN (Online): 2319-7064 \\ Index Copernicus Value (2013): 6.14 | Impact Factor (2014): 5.611}

\section{Experimental animals}

Sixty (60) male Wistar strain rats weighing 100-150 g were procured from National Veterinary Research Instituted VOM, Jos plateau state. They rats were housed in plastic cages ( 5 per cage) in a controlled environment. They were allowed to acclimatize for 2 weeks to obtain a weight gain between 180-200 g. During this period they rats were fed on standard rats-chaw diets ad libitum. The study was carried out based on the guidelines for the use and care for laboratory animals.

\section{Preparation of crude extracts}

Root of matured Senna occidentalis plant was shed dried under room temperature and made into powder using mortar and pestle. The extract was obtained from the powder $(150 \mathrm{~g})$ by maceration in $80 \%$ methanol for 2 days at $37^{\circ} \mathrm{C}$ (Abdul et $a l ., 2009)$. The extract was filtered and the excess methanol was evaporated under a reduced pressure in a rotary evaporator at $<50{ }^{\circ} \mathrm{c}$. The dried extract was put in a clean sterile container for further use.

\section{Experimental design}

Animals were randomly divided into six (6) groups with five rats per group; group 1 received distilled water only as normal/control group. Hepatic injury was induced in the five remaining groups through injecting a single intraperitoneal dose of $1.0 \mathrm{ml} / \mathrm{kg}$ body weight $(50 \% \mathrm{v} / \mathrm{v}) \mathrm{CCl}_{4}$ in olive oil for 48 hours. (Shi et al., 2012), the pre-treatment with extract lasted for 7 days before hepatic damage to group III, $\mathrm{IV}, \mathrm{V}$ and group VI was treated with sylmarin drugs before inducing hepatic damage.

\section{Biochemical analysis}

At the end of the experiment, all animals were anaesthetized with diethyl ether vapor. Blood samples were collected by cardiac puncture into a plain tube. The blood samples were allowed to clot. The clotted blood samples were centrifuged in a bench top centrifuge (3000 rpm for10 $\mathrm{min}$ ) to obtain serum. This separated serum was used for the following biochemical analyses: Alanine Aminotransferase (ALT), Aspartate aminotransferase (AST), alkaline phosphotase (ALP), conjugated bilirubin, total bilirubin, albumin and total protein. These tests were assayed using commercially available kits following the manufactures instruction.

\section{Statistical analysis}

All data was expressed as mean \pm S.E.M (standard error mean). Statistical differences between groups was assessed using the SPSS software, version 20 and Results was statistically analyzed by Student's, $t^{\text {ee }}$ test for significant difference between groups.

\section{Result}

Table 1 and 2 showed the qualitative and quantitative Phytochemicals constituents detected in the methanol root extract of Senna occidentalis respectively. Where Saponins $21.5 \pm 0.71 \mathrm{mg} / \mathrm{g}$, Tannins, Alkaloids, Phenols, Flavonoids,
Glycosides, Terpenoids and Steroids were present in the extract but Anthraquinones was absent.

Table 3 also showed the effect of the methanol extract of Senna occidentalis root on serum levels of AST, ALT and ALP in rats. Hepatotoxicity was evidenced by a significant increase $(\mathrm{p}<0.05)$ in the serum level of AST, ALT and ALP in the group treated with only $\mathrm{CCl}_{4}$ when compared with control. Simultaneous administration of the extract with $\mathrm{CCl}_{4}$ significantly reduced $(\mathrm{p}<0.05)$ the level of these enzymes in serum when compared with the group treated with $\mathrm{CCl}_{4}$ only.

Administration of $\mathrm{CCl}_{4}$ alone to rats caused a significant increase $(p<0.05)$ in serum level of conjugated bilirubin and unconjugated bilirubin in Table 4 when compared with controls. Simultaneous administration of 100, 200 and 300 $\mathrm{mg} / \mathrm{kg}$ body weight methanol root extract with $\mathrm{CCl}_{4}$ to rats significantly reduced $(\mathrm{p}<0.05)$ the level of unconjugated bilirubin in serum to the range of the control value. A significant decrease $(p<0.05)$ in concentration of albumin in serum of rats treated with $\mathrm{CCl}_{4}$ only when compared with control was observed (Table 4). The change effected by the administration of $\mathrm{CCl}_{4}$ only was significantly reversed $(\mathrm{p}<$ 0.05 ) by the simultaneous administration of $\mathrm{CCl}_{4}$ with 100 , 200 and $300 \mathrm{mg} / \mathrm{kg}$ body weight of methanol root extract. Treatment of rats with $\mathrm{CCl}_{4}$ alone significantly reduced $(\mathrm{p}<$ $0.05)$ the concentration of total protein in both the liver and the serum when compared with control (Table 4). Simultaneous administration of rats with CCl4 with 100, 200 and $300 \mathrm{mg} / \mathrm{kg}$ body weight of methanol root extract significantly reversed the change $(\mathrm{p}<0.05)$.

Table 4.1: Qualitative Phytochemicals composition of Senna occidentalis root extract.

\begin{tabular}{|l|c|}
\hline Phytochemicals & Inference \\
\hline Saponins & + \\
Tannins & + \\
Alkaloids & + \\
Steroids & + \\
Phenols & + \\
Flavonoids & + \\
Glycosides & + \\
Terpenoids & + \\
Athraqiunones & - \\
\hline
\end{tabular}

Key: $+=$ Presence of Phytochemicals - = Absence of Phytochemicals.

Table 2 Quantitative Estimation of Phytoconstituents of Senna occidentalis root methanol extract $(\mathrm{g} / 100 \mathrm{~g})$

\begin{tabular}{|l|c|}
\hline Phytochemicals & Percentage composition \\
\hline Saponins & $6.0 \pm 0.27$ \\
Flavonoids & $3.5 \pm 0.26$ \\
Terpenoids & $0.4 \pm 0.06$ \\
Alkaloids & $10 \pm 0.68$ \\
Tannins & $7.8 \pm 0.38$ \\
Phenols & $9.9 \pm 0.12$ \\
\hline \multicolumn{2}{|l|}{ Values are expressed as mean \pm SEM: $\mathrm{n}=3$} \\
\hline
\end{tabular}




\section{International Journal of Science and Research (IJSR) ISSN (Online): 2319-7064}

Index Copernicus Value (2013): 6.14 | Impact Factor (2014): 5.611

Table 3: Effect of Methanol Root Extract of Senna occidentalis on $\mathrm{CCL}_{4}$ Induced Hepatic Damage in Rats

\begin{tabular}{|c|c|c|c|}
\hline Treatment & AST (IU) & ALT (IU) & ALP (IU) \\
\hline Normal control & $16.91 \pm 1.45$ & $21.31 \pm 3.02$ & $60.77 \pm 4.21$ \\
\hline $\mathrm{CCL}_{4}(1.5 \mathrm{ml} \mathrm{kg})$ control & $210.44 \pm 11.61^{2}$ & $134.00=10.04^{\mathrm{ab}}$ & $213.07 \pm 12.41^{\mathrm{sb}}$ \\
\hline $100 \mathrm{mg} / \mathrm{kg}$ bwt $+\mathrm{CCL}_{4}$ & $179.11=7.15^{\mathrm{eb}}$ & $120.25=3.14^{c}$ & $199.154=9.16^{\circ}$ \\
\hline $200 \mathrm{mg} / \mathrm{kg}$ bwt $+\mathrm{CCL}_{4}$ & $78.45 \pm 5.59 \mathrm{cb}$ & $94.44 \pm 6.78^{\circ}$ & $132.74=5.81^{\circ}$ \\
\hline $300 \mathrm{mg} / \mathrm{kg} \mathrm{bwt}+\mathrm{CCL}_{4}$ & $33.74=4.30^{\circ}$ & $32.78=3.09^{\circ}$ & $97.87 \pm 5.92^{\circ}$ \\
\hline Sylmarin bwt + $\mathrm{CCL}_{4}$ & $18.28=2.86^{\circ}$ & $28.2 \pm 1.03^{c}$ & $82.97 \pm 6.07^{\mathrm{e}}$ \\
\hline
\end{tabular}

Values are expressed as mean \pm SEM: $n=5$

${ }^{a}$ significantly higher than normal control $\mathrm{p}<0.05$

${ }^{\mathrm{c}}$ Significantly lower than $\mathrm{CCL}_{4}$ control

${ }^{\mathrm{b}}$ Significantly higher than the sylmarin control

Table 4: Effect of Methanol Root Extract of Senna occidentalis on $\mathrm{CCL}_{4}$ Induced Hepatic Damage in Rats

\begin{tabular}{|c|c|c|c|c|}
\hline Treatment & TB ( $\mathrm{mg} / \mathrm{dl})$ & $\mathrm{CB}(\mathrm{mg} / \mathrm{dl})$ & $\mathrm{TP}(\mathrm{g} / \mathrm{L})$ & $\operatorname{ALB}(\mathrm{g} / \mathrm{l})$ \\
\hline Normal & $0.89 \pm 0.06$ & $0.28=0.10$ & $43.15 \pm 3.71^{*}$ & $39.36 \pm 2.42^{8}$ \\
\hline $\mathrm{CCL}_{4}(1.5 \mathrm{ml} / \mathrm{kg} \mathrm{t}$ & $=0.14^{a b}$ & $=0.54^{\mathrm{ab}}$ & $30.25 \pm 0.42$ & 0.65 \\
\hline $100 \mathrm{mg} / \mathrm{kg}$ bwt + & $1.63=0.21^{\mathrm{cb}}$ & $0.94=0.03 \mathrm{cb}$ & $32.47 \pm 0.67$ & $32.42=0.68$ \\
\hline $200 \mathrm{mg}$ & $1.15=0.26^{\mathrm{eb}}$ & $0.54 \pm 0.084^{c b}$ & $39.30=0.17^{*}$ & $36.34 \pm 1.87^{*}$ \\
\hline $300 \mathrm{mg} / \mathrm{k}$ & $0.90=0.015^{\mathrm{c}}$ & $0.41=0.07 \mathrm{cb}$ & $41.31=0.87^{*}$ & $38.34=0.44^{*}$ \\
\hline Sylmarin + $\mathrm{CCL}_{4}$ bwt & $0.72 \pm 0.04^{c}$ & $0.15 \pm 0.014^{c}$ & $44.63=0.23^{*}$ & $40.63 \pm 0.42^{*}$ \\
\hline
\end{tabular}

Values are expressed as mean \pm SEM: $n=5$

Keys: ${ }^{a}$ significantly higher than normal control $\mathrm{p}<0.05$

${ }^{\mathrm{c}}$ Significantly lower than $\mathrm{CCL}_{4}$ control

*Significantly higher than $\mathrm{CCL}_{4}$

${ }^{\mathrm{b}}$ Significantly higher than the sylmarin control

\section{Discussion}

The activity of AST, ALT and ALP are normally found in the cytoplasm (Mohammed et al., 2009), which are released into the blood circulation after cellular damage (Sallie et al., 1991). In this research, treatment of animals with single dose of $\mathrm{CCl}_{4}$ caused significant $(\mathrm{P}<0.05)$ elevation in the levels of serum ALT, AST, ALP, unconjugated bilirubin and conjugated bilirubin as well as significant decreased in level of serum total protein and albumin compared to the normal control. This current study which showed a similar rise in the levels of ALT, AST, ALP and bilirubin after injecting rats subcutaneously with $\mathrm{CCl}_{4}$ to induce liver injury as early reported by Bahar et al. (2003) a marked elevation in the serum levels of ALT, AST and ALP in $\mathrm{CCl}_{4}$ treated animals compared to that of the normal control animals. this findings also showed a significant elevation in serum values of ALT and AST in rats exposed to a single toxic non-fatal dose of $\mathrm{CCl}_{4}$ as early reported by El-Dosuky et al., (1982), Anupam et al. (1995) and all this changes is due to free radicals which been reported as the predominant mechanism of hepatotoxicity (Gregus and Klaassen, 1995). The decreased in serum total protein and albumin serum level may be due to the interaction of $\mathrm{CCl}_{4}$ with protein molecules leading to an impairment of cellular processes. The same observation was earlier suggested by Chung et al., 201).The critical process underlying $\mathrm{CCl}_{4}$ hepatotoxicity is the combining effect of both lipid peroxidation and the covalent binding of $\mathrm{CCl}_{4}$ reactive metabolites to lipids and proteins (Masuda and Nakamura, 1990).

The liver cells damage was evidenced by the significant increase $(\mathrm{p}<0.05)$ in the level of unconjugated bilirubin in the serum of the group treated with only $\mathrm{CCl}_{4}$ when compared with the normal control group. Increase in the level of unconjugated bilirubin in the blood may result from a defect in the function of the liver to conjugate the bilirubin being produced (Dennis and Mark 1996), this result from bilirubin being the main bile pigment that is formed from the breakdown of heme in the red blood cells. It is transported to the liver where it is secreted by the liver into the bile. Conjugation of bilirubin is a prerequisite for its excretion into the bile (Van et al., 2012).

Subsequently the normalization of these enzymes suggests that Senna occidentalis extract root methanol was capable of regeneration parenchymal cells, thus protecting against membrane fragility consequently and minimizing the leakage of liver enzymes into blood circulation. This is in agreement with the commonly accepted view that serum levels of transaminases return to normal with the healing of hepatic parenchyma and the regeneration of hepatocytes (Anusha et al., 2011). It is therefore, a clear manifestation of hepatoprotective effect of the extracts which may be due antioxidant activity of phenolic and Flavonoids present in extracts (Stankovic et al., 2014).

Significant $(\mathrm{p}<0.05)$ decrease in conjugated bilirubin and unconjugated bilirubin levels in animals treated with 200 and $300 \mathrm{mg} / \mathrm{kg}$ body weight compared to $\mathrm{CCL}_{4}$ control group was observed and this reduction of the conjugated and unconjugated bilirubin levels by the methanol root extract suggests that the extract might have activated the constitutive androstane receptor (CAR) which is a key regulator in bilirubin clearance in the liver (Saini et al., 2004). The primary function of CAR in the bilirubin clearance pathway is to direct a coordinate response to elevated levels of bilirubin by increasing the hepatic expression of each component of the pathway (Saini et al., 2004).

\section{Volume 5 Issue 2, February 2016}




\section{International Journal of Science and Research (IJSR) \\ ISSN (Online): 2319-7064}

Index Copernicus Value (2013): 6.14 | Impact Factor (2014): 5.611

They results also showed significant increase $(p<0.05)$ in serum albumin and total protein followed the same trend; it thus implicates the same mechanism by which the extract exerts its effect on these liver indices. The administration of $\mathrm{CCl}_{4}$ alone may adversely interfere with protein metabolism probably by inhibiting the synthesis of proteins such as albumin in the liver. Administration of $\mathrm{CCl}_{4}$ to rats already treated with 200 and $300 \mathrm{mg} / \mathrm{kg}$ body weight methanol root extract which significantly reversed $(\mathrm{p}<0.05)$ these changes might have interfered with protein synthesis. This observation suggested that hepatoprotective activity of Senna occidentalis root extract possessed or exhibited protective activity against liver injury cause by $\mathrm{CCL}_{4}$ administration. Stimulation of protein synthesis has been advanced as a contributory hepatoprotective mechanism which accelerates regeneration of cells (Hayato and Shin 2012).

It has been shown that $\mathrm{CC}_{4}$ induced lipid peroxidation can be obstructed by natural antioxidants (Subramanian et al., 1999). In the present study Senna occidentalis methanol root extract possessed In vivo hepatoprotective activity as suggested by the observation so far. The hepatoprotective activity of Senna occidentalis methanol root extract may be due to its various bioactive compounds contained in the extract.

\section{References}

[1] Anupam Bishayee, Alok Sarkar, Malay Chatterjee, (1995). Hepatoprotective activity of carrot (Daucus carota L.) against carbon tetrachloride intoxication in mouse liver. Journal of Ethnopharmacol. 47:69-74.

[2] Anju D, Arun N, Sayeed A (2012). A recent update in research on the antihepatotoxic potential of medicinal plants. February. J. Chin. Integr. Med: 10:2.

[3] Anusha M, Venkateswarlu M, Prabhakaran V, Taj SS, Kumari BP, Ranganayakulu D. (2011) Hepatoprotective activity of aqueous extract of Portulaca oleracea in combination with lycopene in rats. Indian Journal of Pharmacol. 43, 5 :563-567.

[4] Bahar A, Tawfeq AA, Abu BS (2003). Antihepatotoxic activity of seeds of Cichorium intybus". Journal of Ethnopharmacol. 87:237-240.

[5] Bukhsh Ellashi, Malik Akber Salman, Saeed Ahmad Sheikh and Summra Erum (2012) hepatoprotective and hepatocurative properties of alcoholic extract of Carthamus oxyacantha seeds Africa journal plant science 8 (1) 34-41.

[6] Chung MP, Yeon SC, Hyun JY, Chung WC, Young SS (2010). Amelioration of oxidative stress by dandelion extract through CYP2E1 suppression against acute liver injury induced by carbon tetrachloride in spraguedawley rats. Phytother. Res. 24, 9:1347-1353.

[7] Delachiave, MEA. and De. Pincho, Z., (2003). Scarification, temperature and light in germination of Senna occidentalis (Caesalpinaceae). Seed Science and Technology. 31, 225-230.

[8] Dennis Lee and Mark, MD (1996). Journal of Applied Pharmaceutical Science. 4 (3), 123-133

[9] Dwivedi, Shri Chinmay and Rakesh Kumar, (1998). Evaluation of $\mathrm{n}$. Cassia occidentalis leaf extract on development and damage caused by Trogoderma granarium Khapra Beetle. Journal of Ecotoxicological and Environmental Monitoring. 8, 55-58.

[10] Drew A. (2000), Drug discovery today and tomorrow. Drug Discovery Today 5 (1), 2-4.

[11]El-Desouky EA, Hanna RA, Ghazy AM (1982). A comparison of enzymes parameters used to assess liver damage by $\mathrm{CCl}_{4}$. Res. Bull. Ain Shams University 2046:1.

[12]Etuk EU, Agaie BM, Ladan MJ, Garba I. (2009) The modulatory effect of Cochlospermum tinctorium a rich aqueous root extract on liver damage induced by carbon tetrachloride in rats. African Journal of Pharmacology 3(4), 151-157.

[13] Gregus Z., and Kiwassen C., (1995). Mechanism of toxicity. In: Klaassen CD (Ed) The Basic Science of Poisons, 5th ed. New York, McGraw-Hill.pp. 35-74.

[14] Hayato Nakagawa and Shin Maeda (2012). Molecular mechanism of liver in liver injury and hepatocarcinogenesis: focusing on the role of stress activated MAPK. Journal of pathology research international 2012:14.

[15] Kuppuswamy RG., Anbuganapathi V., Gokulakrishnan B., Rajkapoor B., Jayakar H., Manian,S. (2003) Effect of Dried Fruits of Solanum nigrum linn against CCl4 Induced Hepatic Damage in Rats. Journal of Biology and Pharmaceutical 26, 1618-1619.

[16] Masuda Y, Nakamura Y (1990). Effect of oxygen deficiency and calcium omission on CC14 in isolated perfused livers from phenobarbutal pretreated rats. Biochemical Pharmacy . 40, 1865-1876.

[17] Mohamed RA, Ramadan RS, Ahmed LA. (2009) Effect of substituting pumpkin seed protein isolate for caseinon serum liver enzymes, lipid profile and antioxidant enzymes in $\mathrm{CCl}_{4}$-intoxicated rats. Adv Biol Res.3 (1-2):9-15.

[18] Palsson, Katinka. and Thomas G.T Jaenson, 1999. Plant products used as mosquito repellents in Guinea Bissau, West Africa. Acta Tropica. 72, 39-52.

[19]Reitman S. and Frankel S. (1957) A colorimetric method for the determination of serum glutamic oxalacetic and glutamic pyruvic transaminases. American journal of clinical pathology 28 (1), 56-63.

[20] Saini Sp, Sonodaj, Xu 1, Toma D, Uppal H, Mu Y, Ren S, Moored DD, Evans RM, and Xie W (2004) A Novel constitutive Androstane Receptor-mediated and CYP3A independent pathway of bile acid detoxification. Journal of mol pharmacology 65:292-300.

[21] Sallie R, Tredger JM, William R (1991). Drugs and the liver biopharmaceutical drug disposition. 12:251-259.

[22] Samy, R. Perumal. and Savarimuthu Ignacimuthu, 2000. Antibacterial activity of some folklore medicinal plants used by tribals in Western Ghats of India. Journal of Ethnopharmacology, 69. 63-71.

[23] Shi H., Dong L., Jiang J., Zhao J., Zhao G., Dang X., Lu X., and Jia M. (2013) Chlorogenic acid reduces liver inflammation and fibrosis through inhibition of toll-like receptor 4 signaling pathway. Journal of Toxicology $\mathbf{1 0 .}$ 1016.

[24] Stankovic Milan, Topuzovic .M, Markovic A, Pavlovic D, Solujic S, and Niciforovic Nede (2014). Antioxidant activity, phenol and flavonoid content of different Teucrium chamaedrys $l$. extracts journals of

\section{Volume 5 Issue 2, February 2016}




\section{International Journal of Science and Research (IJSR) \\ ISSN (Online): 2319-7064}

Index Copernicus Value (2013): 6.14 | Impact Factor (2014): 5.611

biotechnology and biotechnological equipments 24: 8286.

[25] Subramanian LR, Selvam AL, Mudaliar (1999). Prevention of $\mathrm{CCl}_{4}$ induced hepatotoxicity by aqueous extract of Tumeric. Nutr. Res. 19: 429-441.

[26] Van de Steeg E, Stanecky V, Hartmannova H, Noskov L, Hrebicek M, Wagenaar E, Van Esch A, de wart DR, Oude Elferink PR, Kenworthy KE, Sticovac E, alEdreesi M. Knisely AS, Kmoch S, Jirsa M, Schinkel AH (2012). Complete OATPB1 and OATP1B3 deficiency cause human Rotor syndrome by interrupting conjugated bilirubin re-uptake into the liver. Journal of clinical investment 122 (2) 519-528.

[27] World Health Organisation WHO (2011). Traditional medicine in some Asian and African countries. Medicinal plants. Journal of Ethnopharmacol. 56:1337.

[28] World Health Organisation WHO (2003). Fifth-Six World Health Assembly report on traditional Medicine. 